\title{
Race Preferences and Race Privileges
}

\author{
MICHAEL K. BROWN, MARTIN CARNOY, \\ ELLIOTT CURRIE, TROY DUSTER, DAVID B. OPPENHEIMER, \\ MARJORIE M. SHULTZ, AND DAVID WELLMAN
}

At the beginning of the twentieth century, the African American leader and scholar W. E. B. Du Bois declared that the "problem of the twentieth century" was "the problem of the color line." Today, as a new century begins, race is still a pervasive and troubling fault line running through American life. We are not divided because we fail to "get along," as Rodney King lamented after the Los Angeles riots a decade ago. Nor is it because diehard advocates of affirmative action insist on stirring up racial discord. What divides Americans is profound disagreement over the legacy of the civil rights movement. At the core of our national debate are very different opinions about the meaning of race in contemporary America and the prospects for racial equality in the future.

The crude racial prejudice of the Jim Crow era has been discredited and replaced by a new understanding of race and racial inequality. This new understanding began with a backlash against the Great Society and took hold after the Reagan-Bush revolution in the I 980 s. The current set of beliefs about race rests on three tenets held by many white Americans. First, they believe the civil rights revolution was successful, and they wholeheartedly accept the principles enshrined in civil rights laws. They assume civil rights laws ended racial inequality by striking down legal segregation and outlawing discrimination against workers and voters. They think racism has been eradicated even though racist hotheads can still be found throughout America. While potentially dangerous, racial extremists are considered a tiny minority who occupy political space only on the fringes of mainstream white America.

Second, if vestiges of racial inequality persist, they believe that is because blacks have failed to take advantage of opportunities created by the civil rights revolution. In their view, if blacks are less successful than whites, it is not because America is still a racist society. In fact, a substantial majority 
believe that black Americans do not try hard enough to succeed and "with the connivance of government, they take what they have not earned."

Finally, most white Americans think the United States is rapidly becoming a color-blind society, and they see little need or justification for affirmative action or other color-conscious policies. Inspired by the ideals so eloquently expressed in Martin Luther King Jr.'s "I have a dream" speech, they embrace his vision of a color-blind America and look forward to the day when race will not determine one's fate, when a person is evaluated, in King's words, by the content of one's character rather than the color of one's skin.

Jim Sleeper echoes these sentiments. Author of a caustic critique of white liberals and civil rights leaders, he rejects any suggestion that Du Bois's warning is still relevant to America's racial divide. The nation's future lies in a color-blind society, he believes, and "it is America's destiny to show the world how to eliminate racial differences - culturally, morally, and even physically - as factors in human striving." 2 If Americans remain racially divided, he asserts, it is because we have abandoned "the great achievement of the civil rights era - the hopeful consensus that formed in the I960s around King's vision of a single, shared community." Tamar Jacoby agrees. The author of a lengthy study of racial conflict in three cities, she attributes the failure to create a color-blind society to a "new" black separatism and the "condescension of well-meaning whites who think that they are advancing race relations by encouraging alienation and identity politics." ${ }^{3}$

On the surface at least, these beliefs about race are compelling. They appeal to widely held principles like fairness and equality of opportunity, diminishing the differences between liberals and conservatives. More important, they also resonate with the experiences of many white Americans. In an era when economic inequality is growing, when many families stand still financially despite earning two and sometimes three incomes, these beliefs provide a convenient explanation for their circumstances. Historically, class inequality has exacerbated racial inequality, and the present is no different. The idea that lazy blacks get government handouts inflames white men whose real wages barely increased during the I990s economic boom. And for whites turned away from elite colleges and professional schools that accept African Americans, these notions provide an outlet for deep resentment. ${ }^{4}$

The goal of a color-blind America is an old and cherished idea. When segregation was legal and racial classification determined where one sat or drank or worked or lived or went to school, color-blindness meant abolishing the color-coded laws of southern apartheid. Color-blindness was the opposite of Jim Crow. It was liberals who championed the idea of colorblindness in the I960s, while conservatives were ardent defenders of racial 
segregation. ${ }^{5}$ Thirty-five years ago many Americans, inspired by the civil rights movement's transcendent vision of an inclusive society, passionately searched for solutions to the problem of racial inequality. While nationalists on both ends were often strident, apocalyptic, and pessimistic, the liberal architects of color-blind politics were optimistic and confident that this approach would generate greater equality between the races.

The triumph of the civil rights movement, however, exposed the limits of color-blind social policy: What good were civil rights if one was too poor to use them? As Martin Luther King Jr. told his aide Bayard Rustin after the explosion in Watts, "I worked to get these people the right to eat hamburgers, and now I've got to do something . . to help them get the money to buy it." 6 And in a posthumously published essay, he wrote about what it would take to achieve a genuinely inclusive society. His vision went beyond color-blind civil rights laws: "Many whites who concede that Negroes should have equal access to public facilities and the untrammeled right to vote cannot understand that we do not intend to remain in the basement of the economic structure; they cannot understand why a porter or housemaid would dare dream of a day when his work will be more useful, more remunerative and a pathway to rising opportunity. This incomprehension is a heavy burden in our efforts to win white allies for the long struggle."

Too many whites in America have failed to heed Martin Luther King Jr.'s warning of what it would take to achieve a genuinely inclusive society. Writing twenty-five years after Brown v. Board of Education was decided, Judge Robert L. Carter, who argued the case before the Supreme Court alongside Thurgood Marshall, observed, "It was not until Brown I was decided that blacks were able to understand that the fundamental vice was not legally enforced racial segregation itself; that this was a mere by-product, a symptom of the greater and more pernicious disease - white supremacy." Unlike those who believe that the dream of integration was subverted by colorconscious policies, Carter pointed out that "white supremacy is no mere regional contamination. It infects us nationwide," he wrote, "and remains in the basic virus that has debilitated blacks' efforts to secure equality in this country." 8

With the clarity of hindsight, we can now see that it was naïve to believe America could wipe out three hundred years of physical, legal, cultural, spiritual, and political oppression based on race in a mere thirty years. The belief, even the hope, that the nation would glide into color-blindness was foolish. Indeed, there are good reasons to believe the current goal of a colorblind society is at least as naïve as the optimism of the I960s and conveniently masks color-coded privileges. 
The conflict over color-conscious public policies poses a powerful challenge: the issue in the debate goes beyond the future of specific policies to the very meaning of racial equality and inclusion. Advocates of color-blind policies believe that the defenders of color-conscious remedies to achieve racial justice are separatists who practice "identity politics." They oppose raceconscious solutions on the grounds that racial inclusion requires only that individuals be treated similarly under the law - no more, no less.

Those of us who disagree wonder whether it would be fair, even if it were possible and desirable, to now use color-blind and race-neutral criteria when people apply for jobs, adoptions, home loans or second mortgages, and college admissions. Racial equality requires social and political changes that go beyond superficially equal access or treatment.

Today, many white Americans are concerned only with whether they are, individually, guilty of something called racism. Having examined their souls and concluded that they are not personally guilty of any direct act of discrimination, many whites convince themselves that they are not racists and then wash their hands of the problem posed by persistent racial inequality. This predilection to search for personal guilt has been reinforced by a Supreme Court that analogously locates the constitutional problem of racial injustice solely in an individual's intent to discriminate.

But if Americans go no deeper than an inquiry into personal guilt, we will stumble backward into the twenty-first century, having come no closer to solving the problem of the color line. Given America's history, why should anyone be surprised to find white privilege so woven into the unexamined institutional practices, habits of mind, and received truths that Americans can barely see it? After three decades of simply admitting Asian American, Latino American, and African American individuals into institutions that remain static in terms of culture, values, and practices, the inadequacy of that solution should be obvious.

The proponents of color-blind policies and their critics have very different understandings of race and of the causes of racial inequality. People's views on these questions have become polarized, meaningful exchange is rare, and the public policy debate has stalemated. For these reasons we think it is time to get beyond the debate over affirmative action or individual guilt and try to figure out why racial inequality continues to be an intractable American problem. Toward that end, we take a careful look at the emerging public understanding of race and racism in America. By thoroughly scrutinizing this evolving perspective and then comparing it to an alternative view, we want to show what is at stake in the current American debate over racial equality and inclusion. 


\section{The Emerging Racial Paradigm}

In the past few years a number of books have appeared that elaborate and refine the new popular understanding of race and racial inequality in America. Besides Jim Sleeper's Liberal Racism (I997) and Tamar Jacoby's Someone Else's House (I998), these include Dinesh D'Souza's The End of Racism (I995), Shelby Steele's A Dream Deferred (I 999), and, most important, Stephen and Abigail Thernstrom's America in Black and White: One Nation Indivisible (I997). These books are promoted as reasoned and factually informed discussions of race in America. All of the authors give this emerging understanding of race and racism the appearance of scholarly heft and intellectual legitimacy. And they represent a diverse set of political positions. Sleeper is a self-identified liberal who believes that color-conscious policies dodge the "reality of social class divisions, which are arguably more fundamental than racial divisions in perpetuating social injustice." D'Souza, Jacoby, Steele, and the Thernstroms are conservatives. ${ }^{9}$ Yet all might be identified as "racial realists," as Alan Wolfe calls the proponents of this perspective.

Although each of these authors has written a very different book about race, all set out to demolish the claims of color-conscious policy advocates and anyone who suggests that racial discrimination is a persistent American problem. Sleeper chastises liberals, either those who protest police mistreatment of blacks or New York Times editorial writers that hold African Americans to lower standards of behavior and accomplishment than whites. Jacoby argues that most of the blame for the failure of integration lies with blacks. And the Thernstroms' book is a not so subtle rejoinder to both the Kerner Commission's national report on race in America, issued in the aftermath of the I960s urban upheavals, and Andrew Hacker's Two Nations: Black and White, Separate, Hostile, Unequal (1992).

The Kerner Commission concluded that "our nation is moving toward two societies, one black, one white-separate and unequal." Hacker updated the Kerner Commission's assessment and provided substantial data documenting the differing conditions and fates of black and white Americans. The Thernstroms wade into the debate accusing critics of the racial status quo like Hacker of polemical posturing. They claim that, by contrast, their analysis complies with standards of neutrality and is committed to factual reporting. America in Black and White, the Thernstroms assert, is a treatise that overcomes ideology and addresses the hard truths. Their stated aim is to move beyond dichotomies, to find more complicated options, to construct an analysis that transcends race. 
Racial realists make three related claims. First, they say that America has made great progress in rectifying racial injustice in the past thirty-five years. The economic divide between whites and blacks, in their view, is exaggerated, and white Americans have been receptive to demands for racial equality. Thus, racism is a thing of the past. Sleeper accuses liberals of a "fixation on color" and says they do not want "truly to 'get beyond racism." "As he sees it, liberals consistently ignore evidence of racial harmony, of blacks and whites working together, or of growing intermarriage between blacks and whites. Instead, they favor a portrait of America as irredeemably racist. ${ }^{10}$

One reason race has remained so politically and socially divisive, racial realists often say, is that ill-conceived and unnecessary race-conscious policies such as affirmative action have been adopted. They believe these policies exacerbate white animosities and do more harm than good. One recent study, in fact, claims that merely mentioning affirmative action to otherwise nonprejudiced whites "increases significantly the likelihood that they will perceive blacks as irresponsible and lazy." 11 Many opponents of affirmative action point out that were it not for these distorting and distracting policies whipping up racial consciousness, race would virtually disappear as a marker of social identity. Race remains divisive, in their view, because raceconscious agitators exploit it to demand race-conscious policies. ${ }^{12}$

The racial realists' second claim is that persistent racial inequalities in income, employment, residence, and political representation cannot be explained by white racism, even though a small percentage of whites remain intransigent racists. As they see it, the problem is the lethargic, incorrigible, and often pathological behavior of people who fail to take responsibility for their own lives. In D'Souza's view, persistent and deep black poverty is attributable to the moral and cultural failure of African Americans, not to discrimination. ${ }^{13}$

For racial realists, color-blindness means, among other things, recognizing black failure. Jacoby reports that she has a note above her desk that reads: "'If you can't call a black thug a thug, you're a racist.' It is," she says, "an idea I stand by." 14 Racial realists charge that blacks and their liberal supporters are unwilling to acknowledge the failures of black people. Sleeper calls this the sin of liberal racism. He thinks that white liberals are guilty of holding blacks to a lower standard. They set "the bar so much lower" for blacks, he writes, "that it denies them the satisfactions of equal accomplishment and opportunity." 15 It is also counterproductive. Jacoby argues that the idea that racism still matters just encourages blacks to believe the fallacy that "all responsibility for change lies with whites." Contemporary allegations of racism, the Thernstroms insist, are mainly a cover, an excuse. Blaming 
whites - arguing that the "white score is always zero" or that "white racism remains a constant" - simply obscures the reality of black failure, self-doubt, and lack of effort. It deflects attention from changing the values and habits of many black people to overcome the "development gap" between blacks and whites, a process Jacoby calls "acculturation."16

The racial realists' final assertion is that the civil rights movement's political failures are caused by the manipulative, expedient behavior of black nationalists and the civil rights establishment. Or, as Alan Wolfe puts the matter in a review of Tamar Jacoby's recent book on integration, "Those who claim to speak in the name of African Americans do not always serve the interests of those for whom they supposedly speak." ${ }^{17}$ The real problem today is not racists like David Duke who still prey on white fears. Instead, the genuine obstacles are misguided black militants like Al Sharpton who overdramatize white racism and white apologists who have a pathological need to feel guilty. Racial realists feel that since black civil rights leaders and militants benefit from government handouts and affirmative action, they have a vested interest in denying racial progress and fomenting racial divisions. Many black politicians, according to the Thernstroms, particularly those elected to Congress, ignore the real needs of their constituents and pursue instead "the rhetoric of racial empowerment" and separatism. ${ }^{18}$

Although racial realists do not claim that racism has ended completely, they want race to disappear. For them, color-blindness is not simply a legal standard; it is a particular kind of social order, one where racial identity is irrelevant. They believe a color-blind society can uncouple individual behavior from group identification, allowing genuine inclusion of all people. In their view, were this allowed to happen, individuals who refused to follow common moral standards would be stigmatized as individuals, not as members of a particular group. ${ }^{19}$

Ironically, like some multiculturalists, racial realists assume that the real problem facing America is not racial discrimination. Instead, it is a problem of recognition and identity, of how people see themselves. Were it not for racial preferences and black hopelessness-helplessness, the Thernstroms believe, race would virtually disappear as a political and social issue in the United States. Racial realists pay only lip service to the idea that racial discrimination matters; they do not seriously investigate how and why racism persists after the dismantling of Jim Crow laws or what causes racial inequality. They would much prefer to slay the evil dragon of racial separatism. For racial realists, upholding Martin Luther King Jr.'s noble dream to transform "the jangling discords of our nation into a beautiful symphony of brotherhood" requires that the words race (and racism) must disappear from our 
political lexicon, and, along with rights, personal responsibility (read black failure) must be acknowledged. ${ }^{20}$

Racial realists did not produce this new assemblage of beliefs about race and racial inequality; they have codified it. And their case against colorconscious public policies has found receptive audiences throughout the country, among both Republicans and Democrats, young and old. But their synthesis of this new set of beliefs was not, as they claim, produced by nonpartisan, neutral observations of race in America. Rather, it is an offshoot of the conservative turn in American politics. Like Dinesh D'Souza and most conservatives, racial realists categorically reject biological explanations for racial inequality while subscribing to the notion that any possibility for reducing racial inequality is undermined by black behavior and values. Like other conservatives, both D'Souza and the Thernstroms believe in a version of racial realism that assumes that government intervention only makes things worse. Racial progress, in this view, is best achieved by letting the free market work its magic. In this instance, conservative ideology, like racial realism, makes a case against color-conscious policies and represents a generation of conservative attacks on liberal social policy. ${ }^{21}$ In an important sense, the public's new understanding of race and racism is both a cause and a consequence of the emergence of modern conservatism, which is the context for the rise of racial realism.

It is time to take a cold, hard look at the case for racial realism and the new understanding of racism that it synthesizes. In the following analysis, we assume people bear certain responsibility for the outcomes of their lives. We do not ignore or make excuses when broadly accepted moral and legal standards are violated. Nor do we attribute every problem and failure in communities of color to persistent racism. But we cannot accept the proposition that racial inequality does not matter and that racism has all but disappeared from American life. In our judgment, the new public understanding subscribes to a false dichotomy: either we have racial prejudice or we have black failure. We think this view is deeply flawed. We present an alternative perspective, one that is sustained by empirical evidence and is more consonant with the realities of race in America as the nation enters the twenty-first century.

We use the term racial realists to refer to individuals who subscribe to the new belief system. Racial realists do not agree on every tenet of the new understanding of racial inequality, and they span, as we have indicated, the political spectrum. However, many of the writers we consider are conservatives, and they combine racial realism with political conservatism. When we analyze their views, we refer to them as conservatives rather than racial realists. 


\section{The Logic of Color-Blind Policies and Free Market Racism}

The racial realists claim that segregation was defeated and white prejudice minimized after Congress passed the 1964 Civil Rights Act and the I965 Voting Rights Act, but that these gains have been derailed by the misguided policies of the civil rights establishment and liberal politicians. They believe that the United States made greater progress in removing racial prejudice and racist behavior in this period than many liberals will acknowledge. The Thernstroms cite big changes in racial attitudes among whites since the I940s as evidence for this assertion. White prejudice, in their estimation, started to decline much earlier than most people realize. The shift began, the Thernstroms argue, in the early I950s. And when the civil rights movement abolished Jim Crow, white racism withered away.

Equating attitudes with institutional practices, the Thernstroms boldly assert that racial inequality substantially diminished between I940 and I970. This progress, they contend, accompanied economic growth and individual achievements in education, not government programs. This claim radically twists the commonly held assumption that civil rights policies were responsible for the growth of the black middle class. There is no question that since the early I940s African Americans have made enormous strides in income, occupation, and education. But the Thernstroms claim that the black middle class made its greatest strides prior to affirmative action policies and government programs designed to assist African Americans. The largest income gains and the greatest reductions in poverty rates, they assert, did not come in the I 960 s but in the two decades following the Great Depression. According to the Thernstroms, Lyndon Johnson's Great Society played a small role in the creation of a flourishing black middle class and the alleviation of black poverty.

This historical account enables the Thernstroms to make an inference that is vital to the new understanding of race and racism. In this reading of history, African American economic progress - narrowing the racial gaps in wages, occupation, employment, and wealth - depends almost entirely on reducing the deficit in black people's levels of education, job skills, and experience. The idea here is that individuals succeed economically when they acquire the skills and experience valued by employers. The Thernstroms, along with many of the writers and scholars on whom they depend, assume that the most important factors that determine economic achievement for blacks are growth of the economy and the opportunity for employers to rationally choose between skilled and unskilled workers in competitive labor markets, not the elimination of institutional practices that systematically 
privilege whites. In this view, racial differences in employment, wages, and family income will presumably disappear as blacks acquire more job-related skills and education. ${ }^{22}$

Not every racial realist accepts the Thernstroms' historical account of black people's economic progress. But many people believe that after the I960s, labor market discrimination was substantially diminished or eliminated and that what matters now is education and job skills. White racism, in their view, has very little to do with black income and wages or persistently high poverty rates in the black community. ${ }^{23}$ It clearly makes much more sense, these people think, to look at the counterproductive and antisocial choices of poor blacks - choices that lead young women to have babies out of wedlock, young men to commit crimes, and young men and women to drop out of school.

When the Thernstroms argue that labor market discrimination was relatively unimportant in the r940s and assert that labor market discrimination is all but gone, they rely on the economic theory of discrimination. This theory assumes that in competitive economic markets, discrimination is short-lived because ruthlessly competitive entrepreneurs will take advantage of the opportunities racial exclusion provides and hire low-wage black workers instead of their high-priced white counterparts. Victims of market discrimination, therefore, will always have an option to work, because some employers will not subordinate their chance to make a profit on cheap black labor to a desire to exclude black workers. In "a world of free access to open markets," the legal scholar Richard Epstein writes, "systematic discrimination, even by a large majority, offers little peril to the isolated minority." 24 Because the theory assumes that competition drives discriminatory employers out of the market, any differences in wages or income must be attributable to differences in education, job skills, or cultural values. In this account, when de jure segregation was demolished by I960s civil rights legislation, blacks were free to compete on a more or less equal basis with whites. As a result, race-conscious policies that guarantee employment or education are not only unnecessary but are also harmful to the free market.

For the Thernstroms, as well as for the full range of racial realists and conservatives who subscribe to this remarkable revisionist history of racism since the 1960 , the main problem facing America was state-sponsored racial discrimination. The difficulty with Jim Crow laws in this view was not that they institutionalized white supremacy and racial domination. The problem with Plessy v. Ferguson ( I 896), which upheld the power of state governments to segregate public facilities and transportation by race, is that it interfered with an unfettered market. According to Epstein, southern politicians were 
catering to the prejudices of white voters by imposing legally binding segregation throughout the South. But these misguided laws made it impossible for employers to hire blacks and pay equal wages to blacks and whites, and this then short-circuited competition in labor markets. In this vein, he is troubled because the Supreme Court did not strike down these laws on the grounds that they interfered with the "liberty of contract," as it did when it struck down minimum wage and hours laws in the North. Epstein argues that even if segregated labor markets were to emerge in a free, competitive economic market, it would be the result of voluntary choices rather than coercion and therefore "must be sharply distinguished from the system of government-mandated segregation on grounds of race." 25

Voluntary, individual choice is crucial to the color-blind worldview one finds in racial realism and to the new understanding of racial inequality that it promotes. Although the civil rights movement demolished publicly sanctioned racist laws, racial realists do not believe civil rights laws were intended or designed to promote integration or to eliminate racial differences in economic status. Color-blindness in this view is a formal guarantee of equality before the law; it only means that government may not treat individuals unfairly or discriminate against them. But being blind to color does not mean that racial differences in income, wages, or status will disappear. According to this version of color-blindness, people will rise or fall according to their own efforts and abilities. The onus of responsibility for success is squarely on the individual.

It should not be surprising, therefore, that these proponents of colorblindness strongly believe affirmative action policies in the late I 960 s twisted and distorted the goals and statutory achievements of the civil rights movement. Affirmative action, in their view, refers to any race-conscious policy that mandates racial integration in schools, the creation of black or Latino majority legislative districts, or preferences in college admissions, employment, and business contracts. In each case, critics argue that the original, laudable goals of the civil rights movement were perverted by arrogant elites - black civil rights leaders, judges, and white liberals - who insisted on imposing their agenda and subverted the dream of a color-blind society.

The Thernstroms are typical of this sentiment. Their account of school desegregation is a classic attack on race-conscious policies. Desegregation was an entirely appropriate goal in their estimation, and it could have been achieved by abolishing Jim Crow laws and constructing school district boundaries that promoted racial balance. But, unfortunately, self-aggrandizing civil rights leaders and radical white liberals replaced this sensible policy with court-ordered busing, together with other forms of forced integration, 
and the results were predictably bad. In their view, the same scenario was played out with race-conscious employment policies, college admissions, business set-asides, and legislative redistricting. So far as the Thernstroms are concerned, all color-conscious policies, like much governmental regulation, are wasteful, make things worse, are prone to corruption, and, in this instance, stir up the reservoirs of racial resentment. If that were not serious enough, the Thernstroms add, none of these policies provide jobs for black students or raise their cognitive abilities.

This is racial realism's intellectual framework. It is reflected in and reinforced by contemporary white American public opinion about issues triggered by race. Persistent racial inequality is accepted as normal; African Americans are thought to be "the cultural architects of their own disadvantage." Lawrence Bobo calls this "laissez-faire racism." 26

\section{The Persistence of Durable Racial Inequality}

This snapshot of race in America is out of focus. Racial realists pose the wrong question. The real issue, so far as they are concerned, is whether the United States has made progress in reducing racial inequality. But every serious student of contemporary racial inequality concedes there has been progress. The Thernstroms remind us repeatedly that the good news "regarding the emergence of a strong black middle class has not received the attention it deserves." ${ }^{27}$ Good tidings, they assert, are neglected because of a volatile mixture of "black anger" and "white guilt." This is hardly true. Every gain the black middle class has made, every uptick in black employment is trumpeted from the rooftops. There is no gainsaying the progress of the black middle class, but to dwell on this amounts to celebrating economic gains while ignoring the large and persistent gaps in economic and social wellbeing between blacks and whites.

An abundance of evidence documents persistently large gaps between blacks and whites in family income, wages, and wealth since the economic boom of the post-World War Two years and after the civil rights revolution. Black families have clearly gained relative to whites over the past fifty-five years, but the absolute income gap between them has widened. In 200I, the real median income of black families was 62 percent of that of whites, only Io points higher than it was in I947, when the ratio was 52 percent. Over the same period, however, the absolute real median income gap doubled, rising from $\$_{10}, 386$ to $\$ 20,469 .^{28}$ (If one compares black family income to that of non-Hispanic whites, a more accurate measure, the ratio is 58 percent, a gap that is largely unchanged since the early I 970 s. $)^{29}$ 
Relative to non-Hispanic white men, black men made income gains between I972 and 200I. Their real median income rose from 60 percent to 67.5 percent of white median income. The absolute gap declined slightly over the same period, falling from $\$_{I I, 624}$ to $\$_{I 0,325}$. (Almost all of black males' income gains came during the economic boom of the late I 990 ; at the beginning of the decade black male income relative to whites' was lower than it was in I972.) The picture for black women is very different. Compared to non-Hispanic white women, black women's real median income declined from 92 percent in 1972 to a low point of 79 percent in I 988 and then rose to 94.5 percent by $200 \mathrm{I}$. The absolute gap in annual income between black and white women is much smaller than the one for the men - a reflection of the wage discrimination experienced by all women. ${ }^{30}$ Large disparities in income remain even when the comparison is restricted to full-time workers, despite a black unemployment rate that is much higher than the rate for whites. ${ }^{31}$

Just as important is the startling persistence of racial inequality in other areas of American life, despite laws passed to address the disparities. Housing and health care are two matters vital to the well-being of individuals and their families, and both illustrate the limits of the civil rights revolution. The I968 Civil Rights Act outlawed housing discrimination, yet African Americans continue to be the most residentially segregated group in the United States (see Massey, part 4). They are far more likely to live in segregated neighborhoods than either Asian Americans or Latinos. ${ }^{32}$ Blacks are much less likely to own a home, and when they can get a mortgage, they receive far less favorable terms than do comparable whites. For example, between I 993 and I998, subprime lending - loans with higher interest rates and predatory foreclosure practices - grew by thirty times in Chicago's black neighborhoods, but by only two and one-half times in white residential areas. Race, not social class, explains this difference: in I998, subprime lenders made 53 percent of the home-equity loans in middle-income black areas but only I 2 percent of the loans in middle-income white areas. ${ }^{33}$

Medicare and Medicaid succeeded in expanding access to health care to many people, a clear example of progress. Racial and income differences in the use of health care facilities, including hospital stays as well as visits to doctors' offices, diminished substantially after these two laws were enacted. These laws made a difference; largely because of Medicaid, black infant mortality rates dropped by half between I960 and I980. Yet racial differences for many health indicators remained unchanged or in some cases widened. The black infant mortality rate remained twice as high as the white rate, and by 1998 it had actually widened. ${ }^{34}$ Moreover, one specialist on race and health care has pointed out that in I 995 "black age-adjusted mortality rates were still I.6I times that of whites, a disparity essentially unchanged 
since $1950 .{ }^{.35}$ In other words, neither the civil rights revolution nor diminishing prejudice have made much difference to racial disparities in mortality, the most fundamental measure of health. Neither income nor poverty status alone can explain these racial differences ${ }^{36}$ (see Williams and Collins, part 4).

One reason for these disparities is that blacks and Latinos are still much less likely to have access to primary care physicians than whites. For example, in South Central Los Angeles, where the population is overwhelmingly African American and Latino, the ratio of primary care physicians to the population is I to I 2,993 . By comparison, in wealthy Bel Air, only a few miles away, the ratio is I to $2 \mathrm{I} 4 .{ }^{37}$ Limited access to primary care shows up in many basic health statistics. David Smith reports that "the proportion of blacks receiving adequate prenatal care, up-to-date childhood immunizations, flu shots as seniors, and cancer screenings lags significantly behind whites, even though most of the financial barriers to such preventive services have been eliminated." 38 African Americans, Latinos, and members of other minority groups account for 75 percent of active cases of tuberculosis, and the Centers for Disease Control reports that blacks are five times as likely to die of asthma as are whites. ${ }^{39}$ Even when blacks have equal access to medical care, recent evidence indicates that significant racial disparities in treatment and care remain. For example, among Medicare beneficiaries of similar age, gender, and income, blacks are 25 percent less likely to have mammography screening for breast cancer and 57 percent less likely to have reduction of hip fracture. ${ }^{40}$

Any credible analysis of race in America at the beginning of the twentyfirst century must confront and account for these durable and persistent inequalities between blacks and whites. Many proponents of racial realism as well as those Americans who subscribe to the new explanation for racial inequality fail to do this for two reasons. First, they ignore or obscure dramatic and persistent facts of racial inequality. Second, the methodological assumptions that guide their investigation of race in America lead them to ignore alternative explanations that more closely "fit" the evidence they do cite. In the following analysis, we address each of these concerns.

\section{The Minimal Relevance of Individual Choice to Durable Racial Inequality}

Today the predominant approach to understanding racial stratification in American life assumes that "social life results chiefly or exclusively from the actions of self-motivated, interest-seeking persons." ${ }^{41}$ For those promulgat- 
ing this view, it is solely the stated intentions and choices of individuals that explain discrimination. It leads writers to focus on individual whites' beliefs about African Americans and civil rights. Throughout America in Black and White, for example, the Thernstroms focus on the positive upward spiral of individual whites' attitudes as measured by public opinion data. The positive shift in expressed attitudes is then assumed, prima facie, to be evidence of behavior. If (white) people say they are not discriminating against blacks, the Thernstroms believe them, and infer that discrimination must be diminishing. In a like manner, persistent racial inequality is attributed to blacks' individual choices of lifestyles and attitudes.

The Thernstroms' assessment of residential discrimination is a prime illustration of how individual intentions and choices are used to explain racial inequality. They do not deny that residential segregation remains very high. Instead, the Thernstroms argue that it has declined somewhat and that this is real evidence of racial progress. ${ }^{42}$ They go on to argue, however, that housing would be even less segregated but for the choices of blacks. Public opinion surveys prove whites are quite willing to accept blacks as neighbors. The problem, they argue, is that public opinion data show blacks would prefer to live in neighborhoods that are at least 50 percent African American. Thus, they conclude that the preferences of blacks, not white racism, produces segregated housing. In other words, present-day segregation is caused by ethnic group loyalty. ${ }^{43}$

Just as the Thernstroms think housing segregation reflects black preferences, Sally Satel, a psychiatrist, contends that racial differences in health and well-being are due to blacks' bad lifestyle choices. Like other conservatives, Satel thinks declining individual prejudice and the elimination of de jure segregation mean that racism is largely a thing of the past. Angered that "accusations of medical bias still linger" decades after segregation has ended, Satel severely criticizes federal funding of studies on racial and ethnic disparities in health care and any suggestion that there is a relationship between blacks' and Latinos' health and discrimination or powerlessness. Satel accuses the public health establishment of neglecting the vital role of individual choices in health outcomes in its rush to analyze social injustice. "Taking responsibility for one's own health comes to be virtually ignored," she complains. ${ }^{44}$

Satel's criticisms about the documentation of racial disparities evade fundamental questions regarding the institutional structure of health care and racially disparate outcomes. By focusing on the stated intentions and choices of individuals, conservatives like the Thernstroms and Satel ignore the systemic and routine practices of white Americans and the consequences of their 
behavior. Whether these actions are motivated by group values and interests or operate through private and public institutions, the inescapable results are harmful to African Americans and other people of color.

When social scientists analyze income, employment, or occupational disparities between categorical groups - blacks-whites, men-women - they assume these gaps in material well-being are due mostly to differences in education and job skills that would affect an individual's productivity and thus that person's ability to succeed in competitive labor markets. Studies of wage discrimination, for example, typically proceed by removing the effects of individual characteristics such as education or experience that might explain wage differences between men and women or between racial groups. Any remaining gap in wages is then attributed to discrimination. Yet as Ruth Milkman and Eleanor Townsley explain, "This approach . . . fails to capture the depth with which gender discrimination and the norms associated with it are embedded in the economic order - in fact, they are embedded so deeply that a willful act of discrimination is not really necessary to maintain gender inequality." 45 One problem with this approach is that an individual's job experience and education may have been shaped by deeply embedded patterns of discrimination - a racially biased allocation of public resources to schools, for example - which means that education is not independent of discrimination. By focusing only on individuals and the skills they bring to the labor market, moreover, analysts obscure the relationship between racial groups, a fundamental element in the development of durable racial inequality.

In the following we will show how and why the specific intentions and choices of individuals regarding racial discrimination or exclusion are frequently irrelevant to the emergence and maintenance of social and economic inequalities in the United States. One cannot assume that individuals are the only appropriate unit of analysis. By making this assumption, Satel, the Thernstroms, and other like-minded interpreters of contemporary racial inequality neglect the collective actions of groups, the role of intermediary institutions, and the cumulative effects of durable racial inequality.

\section{Group Hoarding and the Economic Theory of Discrimination}

As we indicated earlier, the economic theory of labor market discrimination is a theory of individual choice. This one-dimensional theory, however, is empirically flawed. Because it assumes that economic competition drives out discrimination, the theory cannot explain why racial inequality persists once 
education, training, and experience are taken into account. Nor can it explain historical patterns of labor market segregation in both the North and the South. And recent attempts to rescue the theory by attributing differences in the economic success of African Americans and immigrants to cultural values have failed miserably. ${ }^{46}$

While individuals can and do discriminate, labor market discrimination is better understood as a group phenomenon. It is an instance of what Charles Tilly calls opportunity hoarding. This occurs when members of a group acquire and monopolize access to valuable resources or privileges. Most people know that informal networks of family, extended kinship, friendships, and associates are the typical routes to employment. Employers commonly recruit new workers through informal ties and word-of-mouth suggestions; current employees typically identify job candidates. ${ }^{47}$ Because workers tend to be friends and acquaintances of members of the same race and sex, a bias toward re-creating a homogeneous workforce is overwhelming. Discrimination, therefore, can be passive and unobtrusive. One need not be a racist to use one's position to benefit friends and acquaintances, even if it means awarding jobs to whites rather than blacks. ${ }^{48}$

But the process of labor market discrimination is not always so passive. Once members of a group acquire access to resources, they may hoard the resources by denying access to outsiders. Tilly suggests that hoarding can be found in a variety of groups, including immigrants, criminal conspiracies, and even elite military units. ${ }^{49}$ Once a group of employees acquire the best jobs and perks, they can make it difficult for employers to hire outsiders. Insiders can harass unwanted workers by disrupting their work and reducing their value to employers, which can eventually exclude outsiders. Intimidation is a way for insiders to discourage outsiders from even applying for a job. Justifying exclusionary practices with beliefs that denigrate the work habits and skills of excluded workers is the final step in this process. For a long time white workers used the "myth of the machine" - the idea that black workers were incapable of working with machines - to exclude African American workers from skilled, higher paying work. ${ }^{50}$

The Thernstroms assume that changing attitudes toward blacks is the key to reducing racial inequalities in wages, income, and employment. It makes more sense, however, to examine racial labor market competition - a prime example of opportunity hoarding - to get a better handle on a critical determinant of racial inequality. Simple models of discrimination that assume that unequal rewards to otherwise identical workers are motivated by prejudice do not capture the complexity and depth of racially divided labor markets in the twentieth century. When white workers compete for jobs, they use their 
advantages to exclude or subordinate black or Latino workers. Two prominent labor market economists, William Darity Jr. and Samuel Myers Jr., write that discrimination is "endogenously linked to the employment needs of non-black males." Competition between black and white workers intensifies when blacks threaten the status of white workers, either because the blacks have acquired the education and job skills to be competitive or because the job opportunities for whites diminish. ${ }^{51}$ Employers' evaluations of the skills and talents of black workers are often based on negative stereotypes of their productivity rather than on independent assessments of their work. These stereotypes are the residue of racial labor market competition and push black workers to the bottom of the employment queue. ${ }^{52}$

Racial labor market competition is obviously affected by the state of the economy. When economic growth is sluggish or depressed, labor markets are slack and competition for jobs unleashes white racism. Robust economic growth produces tight labor markets as demand for workers rises, and typically has a greater impact on black unemployment rates than on white unemployment rates. Similarly, as high-wage manufacturing jobs are eliminated and whites are displaced, competition intensifies between blacks and whites for low- and moderate-wage service jobs. Job competition based on race can be modified by public policies that regulate wages and access to jobs through full employment or affirmative action policies. But unless or until a third party steps in to demand or induce employers to pursue a different recruitment strategy, a homogeneous racial and gendered workforce will almost inevitably be reproduced.

\section{Institutions and the Routine, Ordinary Generation of Inequality}

Because the realist analysis of racial inequality assumes that racism is produced exclusively by the intentions and choices of individuals, intermediate institutions that play a crucial part in generating and maintaining racial inequality are rarely analyzed. The routine practices of corporations, law firms, banks, athletic teams, labor unions, the military, and educational institutions tend to be ignored or minimized. These institutions are neither scrutinized nor analyzed unless or until they institute strategies that redress past social grievances. Accordingly, advocates of this approach to racial inequality believe that individual access to previously segregated institutions is all that is necessary to redress past racial injustice. They never discuss the ways these institutions might be transformed to accommodate or better engage the groups they formerly excluded. 
Any analysis of racial inequality that routinely neglects organizations and practices that, intentionally or unintentionally, generate or maintain racial inequalities over long periods of time is incomplete and misleading. Such an analysis will be unable, for example, to detect the ways real estate and mortgage lending industries routinely sustain segregated housing markets and discriminate against would-be black homeowners. It will also not notice that discrimination in the criminal justice system is produced by a large number of small decisions by the police that single out young black men, the results of which then extend to their treatment in adult courts.

Nowhere is the folly of neglecting institutional practices more apparent than in the case of racial disparities in health care and mortality. Many health care institutions remain partially segregated despite the end of Jim Crow and federal laws that prohibit distribution of federal funds to institutions that discriminate. The private nursing home industry, for example, has continued to be segregated, largely because for-profit nursing homes are reluctant to accept Medicaid patients, particularly elderly blacks, and state governments have little incentive to enforce civil rights laws. Elderly blacks are therefore less likely to use private nursing homes even though they have a greater need for such care. In Pennsylvania the segregation index for nursing homes is almost as high as the indexes for housing in metropolitan areas. ${ }^{53}$ Moreover, nonwhites are almost twice as likely as whites to be admitted to a nursing home sanctioned by state officials for serious deficiencies in care and facilities. ${ }^{54}$

Segregated and unequal treatment in health care is an endemic problem, though not one that is attributable to the actions of prejudiced individuals. David Barton Smith concludes his detailed assessment of racial disparities in health care by noting that

at least some of the reported differences in rates of drug addiction, sexually transmitted diseases, and possibly even infant mortality reflect differences in the screening and reporting practices of the settings in which care is provided to blacks as opposed to those catering to whites. Such screening and reporting is more likely to be a part of the standard operating procedures of the more urban clinic settings where blacks disproportionately receive their care. In effect, these differences in procedures amount to an institutionalized form of racial profiling. ${ }^{55}$

While there are numerous examples of how economic, educational, and governmental organizations unintentionally produce unequal racial outcomes, it is also the case that certain institutions do better than others in reducing racial inequalities. Some universities that use affirmative action policies, for example, do better at graduating black students than universities 
that admit students strictly on the basis of test scores. Nor do blacks with low test scores always have lower graduation rates, as is typically assumed. It makes sense to focus our attention on institutional practices that mitigate and reduce racial inequalities. These practices will not be discovered, however, when one looks for racism in individual motivations and presumes that people with good intentions will do the right thing if only government gets out of the way.

\section{Cumulative Inequalities}

Inequalities are cumulative, a fact adherents of the new public wisdom on race ignore in their rush to celebrate progress. The story told by the Thernstroms in America in Black and White, for example, is disturbingly, sometimes even stunningly, ahistorical. This may seem surprising because the book does trace race relations over time, from the early I940s to the present, and one of the authors is a prize-winning Harvard historian. Yet the book is insensitive to the ways the past shapes the future. By assuming that behavioral changes are produced by changes in attitudes, the Thernstroms implicitly distinguish between past and present discrimination. ${ }^{56}$ But if discrimination has declined, this means one cannot look to history to explain the persistence of racial inequalities. As a result, proponents of the new understanding of racial inequality are forced to focus on individual motivations. But this neglects how the past has shaped contemporary patterns of racial inequality, and how it continues to constrain the choices of African Americans and other groups. Thus, conservatives and their realist colleagues ignore how the accumulation of wealth - economic, cultural, social, and political capital - molds economic opportunities for all Americans over time, especially blacks, Latinos, and other racial minorities. Wealth matters. At the conclusion of his book on race, wealth, and social policy in the United States, Dalton Conley writes, "One may conclude that the locus of racial inequality no longer lies in the labor market, but rather in class and property relations that, in turn, affect other outcomes. While young African American men may have the opportunity to obtain the same education, income, and wealth as whites, in actuality, they are on a slippery slope, for the discrimination their parents faced in the housing and credit markets sets the stage for perpetual economic disadvantage." 57

When the economy falters, privileged members of society are able to help themselves over the difficult bumps and fluctuations of a market economy. 
Their net worth, not wages, provides the necessary reserves to ride out cyclical downturns in the economy or other disasters. Although the Thernstroms acknowledge racial differences in wealth, they attribute the black deficit to age and family structure. African American families, they argue, are younger and are more likely to be headed by single parents. Both factors militate against wealth accumulation and both, not coincidentally, are characteristics about which individuals exercise some choice. ${ }^{58}$ Differences in the accumulation of wealth between different racial groups, however, are not solely the result of age, family structure, or the inclination to save-blacks and whites save about the same proportions of their income. ${ }^{59}$ In fact, African Americans lost much of the wealth they acquired after the Civil War to white thievery and discrimination. A recent study by the Associated Press found that more than four hundred blacks were dispossessed of more than twentyfour thousand acres of farm and timber land in the South, worth millions of dollars today, through fraud, discrimination by lenders, and other illegal means. ${ }^{60}$

Since inequalities accumulate over generations, an analysis of racial inequalities in the distribution of wealth explodes any distinction between past and present racism. Cumulative inequality undermines racial conservatives' efforts to restrict the effects of racism to the past. Today's racial disparities in wealth reflect the legacies of slavery, Jim Crow, and labor market discrimination (see Oliver and Shapiro, part I).

\section{The Origins of Durable Racial Inequality}

Discussions of racial inequality commonly dwell on only one side of the color line. We talk about black poverty, black unemployment, black crime, and public policies for blacks. We rarely, however, talk about the gains whites receive from the troubles experienced by blacks. Only when the diverging fates of black and white Americans are considered together-within the same analytic framework - will it be possible to move beyond the current stale debate over how to transform the American color line.

In our view, the persistence of racial inequality stems from the long-term effects of labor market discrimination and institutional practices that have created cumulative inequalities by race. The result is a durable pattern of racial stratification. Whites have gained or accumulated opportunities, while African Americans and other racial groups have lost opportunities - they suffer from disaccumulation of the accoutrements of economic opportunity. 
Rather than investigating racial inequality by focusing on individual intentions and choices, we concentrate on the relationship between white accumulation and black and Latino disaccumulation.

\section{Accumulation versus Disaccumulation}

The idea of accumulation is straightforward and can be illustrated with a simple example. Investment counselors routinely explain to their clients the importance of long-term investments. For example, a young couple that set aside just $\$ 40$ a month beginning in I 970 and simply let it sit in an account paying 5 percent interest would accumulate about $\$ 34, \infty 00$, or more than double the amount invested, by the year 2000 . Rolling over modest investments of capital produces an impressive accumulation. Similarly, very small economic and social advantages can have large cumulative effects over many generations.

While accumulation is relatively well understood, there is a parallel and symmetrical idea that is usually ignored. This is the idea of disinvestment and, over time, what might be called disaccumulation. Just as a positive investment of $\$ 40$ can accumulate over time, so too can a negative investment produce a downward spiral. Consider what happens if one owes the Internal Revenue Service a few hundred dollars but allows that debt to go unpaid for a decade. The amount of that debt can increase dramatically and can lead to a debt of several thousand dollars. The amount owed can increase fivefold. From the point of view of the debtor, this is negative accumulation, or for purposes of this discussion, disaccumulation. Just as economic advantages (for example, access to skilled trades) can accumulate, economic disadvantages (such as exclusion from well-paying jobs) can also be compounded over time.

Home ownership is a good example of how the principle of accumulation and disaccumulation works in a racial context. Today's very large gap in median net worth between whites and African Americans is mostly due to the discrepancy in the value of the equity in their respective homes. Blacks experience more difficulty obtaining mortgage loans, and when they do purchase a house, it is usually worth less than a comparable white-owned home. White flight and residential segregation lower the value of black homes. As blacks move into a neighborhood, whites move out, fearing that property values will decline. As whites leave, the fear becomes a reality and housing prices decline. The refusal of white Americans to live in neighborhoods where blacks make up more than 20 percent of the population means that white-owned housing is implicitly more highly valued than black-owned housing. Redlin- 
ing completes the circle: banks refuse to underwrite mortgage loans, or they rate them as a higher risk. As a consequence, when black homeowners can get a loan, they pay higher interest rates for less valuable property. This results in disinvestment in black neighborhoods and translates into fewer amenities, more abandoned buildings, and a lower property tax base. Because white communities do not suffer the consequences of residential disaccumulation - indeed, they receive advantages denied to black homeowners - the value of their housing increases and they accumulate wealth. In this way interlocking patterns of racialized accumulation and disaccumulation create durable inequality. ${ }^{61}$

The distribution of economic wealth is central to any account of racial inequality, but it is not the only dimension of racial accumulation and disaccumulation. For example, inadequate access to health care contributes to disaccumulation in communities of color. Health is fundamental to every aspect of life: without health, a student cannot do well in school; a worker cannot hold a job, much less excel at one; a family member cannot be an effective parent or spouse. Health crises and the staggering costs they impose are critical underlying causes of poverty, homelessness, and bankruptcy. Housing, employment, and education are vital, but without health, and the care necessary to maintain it, the quality of life, indeed life itself, is uncertain. The effect is cumulative. Inadequate prenatal care results in low birth-weight babies, which in turn leads to infant mortality and to severe physical and mental disabilities among those who survive. ${ }^{62}$ One-fifth to one-third of African American children are anemic, and they account for a disproportionate number of children exposed to lead poisoning. Both problems impair intellectual functions and school performance. ${ }^{63}$

Accumulation also includes cultural and social advantages - meeting "the right people" at Harvard, Yale, and Princeton (who can and often do provide a substantial boost to one's career), for example. As we will subsequently document in more depth, a symmetrical process operates in the criminal justice system, with the opposite consequences: judges frequently incarcerate black juveniles rather than sending them home because the court believes these youngsters have fewer outside resources to help them. However well intentioned, these decisions then become part of the juvenile's record, counting against him or her in future scrapes with the criminal justice system. Diverting black youth to state institutions rather than sending them home is analogous to acquiring a small debt that can be compounded. Similarly, critics of affirmative action are correct when they tell black students who have been denied admission to the University of California at Berkeley that "there is nothing wrong with attending UC Riverside." But that is only half the 
story. Elite institutions are saturated with an accumulated legacy of power and privilege along lines of race and gender. The advice to attend Riverside ignores that who you meet at Harvard, Yale, or Princeton - or at Berkeley, Ann Arbor, or Madison - is an important aspect of the accumulation of economic and social advantage.

Many Americans, but particularly conservatives, object to the idea that past discrimination matters in the present. Marianne Means, a columnist for the Hearst newspaper chain, harshly condemns growing black demands for reparations. "We should not be a party," she writes, "to whipping up a guilt trip that is a ploy to get handouts for a social evil that officially ended nearly I40 years ago." 64 Racial realists believe that the accumulation of wealth and power by white Americans over the past 360 years is irrelevant to current patterns of racial stratification, and the use of race-conscious remedies to redress past racial injustices is therefore unnecessary and unfair. As they see it, basing current policies on past practices is wallowing in the past. The main impediment to racial equality, they feel, is state-sponsored discrimination, and the civil rights movement put an end to that. Thus, past discrimination should not matter. Ironically, adherents of this point of view ignore a different form of state-sponsored racial inequality: the use of public policy to advantage whites. Racism is not simply a matter of legal segregation; it is also policies that favor whites.

\section{The Strange Career of Race Preferences in U.S. Public Policy and Law}

Curiously, the current debate over race-conscious remedies assumes that the sole beneficiaries of these policies are blacks and other racial minorities. If, however, affirmative action is defined as "race and gender preferences codified into law and enforced through public policy and social customs," then it is strange and peculiar, arbitrary and incorrect, to suggest that affirmative action began in the summer of I 963 when President John F. Kennedy issued Executive Order I0925. Given the above definition, routinely cited by opponents of affirmative action, the more accurate beginning date for this legal and public policy is $\mathrm{I} 64 \mathrm{I}$. That is when the fledgling jurisdictions that would later become the first states began to specify in law that rights to property, ownership of goods and services, and the right to vote would be restricted by race and gender. In I790, Congress formally restricted citizenship via naturalization to "white persons," a restriction that remained in place until I 952.65

Understood in this way, affirmative action has been in effect for 360 years, not 39. For the first 330 years, the deck was officially and legally stacked on 
behalf of whites and males. ${ }^{66}$ In Dred Scott (I 857 ), Supreme Court Chief Justice Roger Taney posed the matter in remarkably candid terms: "Can a negro, whose ancestors were imported into this country, and sold as slaves, become a member of the political community, formed and brought into existence by the Constitution of the United States, and as such become entitled to all rights, and privileges, and immunities, guaranteed by that instrument to the citizen?" ${ }^{67} \mathrm{He}$ answered his own question in unequivocal language. "We the people,'" wrote Justice Taney, leaving no room for doubt, was never intended to include blacks, slave or free. "Neither Dred Scott nor any other person of African descent," he ruled, "had any citizenship rights which were binding on white American society." The authority cited by Justice Taney in his I 857 Supreme Court ruling was that the Constitution, the courts at every level, the federal government, and the states all routinely denied blacks equal access to rights of citizenship. ${ }^{68}$

Thus, since the inception of the United States, wealth and institutional support have been invested on the white side of the color line, leading to an accumulation of economic and social advantages among European Americans. On the black side, economic and institutional disinvestment has been the practice, resulting in a process of disaccumulation. When President Kennedy issued Executive Order I0925 in the summer of 1963 , he was therefore simply trying to open doors that had been sealed shut for more than three centuries. Now, after only four decades of "racial and gender preferences," a vigorous and partially successful attack is being waged against affirmative action programs that were instituted to reverse three hundred years of disinvestment in black communities. Yet when power and wealth were being invested and accumulated on their side of the color line, white Americans registered hardly any opposition to the arrangement. ${ }^{69}$

\section{The Origins of Modern State-Sponsored Racial Inequality}

One need not go back three hundred years to find the antecedents of contemporary white advantage. The New Deal is the most recent benchmark for the accumulation of white privilege and the generation of black disadvantage. Franklin D. Roosevelt's policies were instrumental to both the cause of racial equality and the perpetuation of racial inequality. New Deal agricultural policies paved the way for the mechanization of southern agriculture and precipitated black (and white) migration to the North and the entry of blacks into manufacturing jobs. The Wagner Act legalized unions; minimum wage laws put an economic floor under all workers; the Social Security Act gave workers a measure of security; and the Employment Act of I946 codified 
the government's responsibility for aggregate employment and price levels. These policies, combined with postwar economic growth, undermined the prewar northern racial order, set in motion changes that would dismantle Jim Crow, and reduced black as well as white poverty.

African Americans benefited from New Deal policies. They gained from the growth of public employment and governmental transfers like social security and welfare. The Great Society went further, reducing racial inequality, ameliorating poverty among the black poor, and helping to build a new black middle class. But if federal social policy promoted racial equality, it also created and sustained racial hierarchies. Welfare states are as much instruments of stratification as they are of equality. The New Deal's classbased, or race-neutral, social policies did not affect blacks and whites in identical ways. Federal social policy contributed disproportionately to the prosperity of the white middle class from the I 940 os on. Whites received more from the New Deal than old-age protection and insurance against the business cycle. Housing subsidies paved the way for a white exodus to the suburbs; federal tax breaks secured union-bargained health and pension benefits and lowered the cost to workers; veterans' benefits were an avenue of upward mobility for many white men. To assume that government policies benefited only blacks or were color-blind, as many white Americans commonly believe, is like looking at the world with one eye.

Three laws passed by Congress in the mid-I930s were instrumental in generating the pattern of racial stratification that emerged during the New Deal: the Social Security Act, the Wagner Act, and the Federal Housing Act. These laws contributed to the accumulation of wealth in white households, and they did more than any other combination of factors to sow and nurture the seeds of the future urban ghetto and produce a welfare system in which recipients would be disproportionately black. It is commonly assumed that the New Deal was based on broad and inclusive policies. While there is some truth to the claim that Roosevelt's New Deal was designed, as Jill Quadagno states it, to provide a "floor of protection for the industrial working class," it was riddled with discrimination. Brokered compromises over New Deal labor and social policies also reinforced racial segregation through social welfare programs, labor policy, and housing policy. ${ }^{70}$ How and why did this happen?

Although the Social Security Act created a work-related social right to an old-age pension and unemployment compensation, Congress defied the Roosevelt administration and explicitly excluded domestic and agricultural workers from coverage. It also exempted public employees as well as workers in nonprofit, voluntary organizations. Only 53 percent of all workers, about 26 million people, were initially covered by the old-age insurance title 
of the Social Security Act, and less than half of all workers were covered by unemployment compensation. Congress subsequently excluded these exempt workers from the Wagner Act and the I93 8 Fair Labor Standards Act as well. ${ }^{71}$

Congress's rejection of universal coverage was not a race-neutral decision undertaken because, as some people claimed at the time, it was difficult to collect payroll taxes from agricultural and domestic workers. As Charles Houston, dean of the Howard University Law School, told the Senate Finance Committee, "It [the Social Security bill] looks like a sieve with the holes just big enough for the majority of Negroes to fall through." Almost three-fifths of the black labor force was denied coverage. When self-employed black sharecroppers are added to the list of excluded workers, it is likely that threequarters or more of African Americans were denied benefits and the protection of federal law. Black women, of whom 90 percent were domestic workers, were especially disadvantaged by these occupational exclusions. ${ }^{72}$

Agricultural and domestic workers were excluded largely because southern legislators refused to allow implementation of any national social welfare policies that included black workers. Roosevelt presided over a fragile coalition of northern industrial workers and southern whites bound to an agrarian economic order. Although blacks began to leave the party of Lincoln for the party of Roosevelt, three-quarters of the African American population still lived in the South, where they could not vote. Southerners feared that federal social policies would raise the pay of southern black workers and sharecroppers and that this in turn would undermine their system of racial apartheid. Black criticisms of the legislation were ignored as Roosevelt acquiesced to southern demands, believing he could not defy powerful southern committee chairmen and still pass needed social welfare legislation.

As black workers moved north into industrial jobs, they were eventually included under the Social Security Act, and Congress ultimately extended coverage of old-age insurance to agricultural workers in I950 and I954. Although the Social Security Administration made every effort to treat black and white workers equally, black workers were nevertheless severely disadvantaged by the work-related eligibility provisions of the Social Security Act. Both old-age insurance and unemployment compensation rewarded stable, long-term employment and penalized intermittent employment regardless of the reason. In the name of fiscal integrity, the architects of social insurance in the I930s were adamant that malingerers, those on relief, and those weakly attached to the labor market be excluded from eligibility and their benefits limited. Due to labor market discrimination and the seasonal nature of agricultural labor, many blacks have not had stable, long-term employment rec- 
ords. Thus, they have had only limited eligibility for old-age and unemployment benefits.

The racial consequences of wage-related eligibility provisions were already apparent in the I930s. Because labor market discrimination lowers the wages of black workers relative to white workers or denies them employment altogether, blacks receive lower benefits than whites from old-age insurance and unemployment compensation or are denied access altogether. By I939, for example, only 20 percent of white workers who worked in industries covered by social insurance and who paid payroll taxes for old-age insurance were uninsured, but more than twice as many black workers $(42$ percent) were uninsured. ${ }^{73}$ From the outset, social security transferred income from African American workers to white workers. This disparity continues today. Even though most black workers are currently covered by social security, on average they still receive lower benefits than whites and pay a higher proportion of their income in social security taxes. ${ }^{74}$ Like old-age insurance, there is little evidence of overt discrimination in unemployment compensation: eligible black workers are almost as likely as white workers are to receive benefits. But because states imposed strict eligibility requirements during the I940s and I950s, black workers were disproportionately excluded. ${ }^{75}$ Social insurance is neither universal nor race-neutral.

In combination, labor market discrimination and work-related eligibility requirements excluded blacks from work and social insurance programs in the I930s, forcing many to go on relief and later on welfare and Aid to Dependent Children. In fact, most black women were excluded from the unemployment compensation system until the late I960s. This is because domestic workers were statutorily excluded from unemployment compensation, and as late as the I950s more than half of all black women in the civilian labor force still worked as domestics. Unemployed black women typically had nowhere to turn but welfare, and this is exactly what they did. By the I960s, African Americans accounted for two-fifths of all welfare recipients, a participation rate that did not change much even when the welfare rolls expanded in the I960s. It is labor market discrimination and New Deal social policies, not welfare, as the conservatives believe, that has harmed black families. The problem cannot be explained by a pathological black family structure. ${ }^{76}$

Social insurance in the United States has operated much like a sieve, just as Charles Houston predicted, and blacks have fallen through the holes. The Wagner Act and the I937 Housing Act compounded the problem, enlarging the holes in the sieve. Sometimes labeled the Magna Charta of the labor movement, the I935 Wagner Act was, upon closer inspection, the 
Magna Charta of white labor. Black leaders tried to add an antidiscrimination amendment to the law, but the American Federation of Labor and the white southerners who controlled key congressional committees fought it. As a result, the final version excluded black workers. The law legalized the closed shop, which, as Roy Wilkins of the NAACP pointed out, would empower "organized labor to exclude from employment in any industry those who do not belong to a union." The law also outlawed strikebreaking, a weapon black workers had used successfully to force their way into northern industries. Preventing blacks from entering into newly protected labor unions meant that black workers were subject to the racist inclinations of white workers. ${ }^{77}$ One of the consequences of the Wagner Act's failure to protect black workers was that union rules confined them to low-wage unskilled jobs. When these jobs were eliminated as businesses modernized after World War Two, black unskilled workers were replaced by automated manufacturing technologies. ${ }^{78}$ Thus, the current high levels of black unemployment can be traced directly to New Deal legislation that allowed white workers to deny job opportunities to blacks.

State-sponsored racial inequality was also augmented by a third set of New Deal policies: federal housing and urban renewal legislation. These policies sealed the fate of America's cities by establishing "apartheid without walls." Contrary to the commonly held notion that white flight is responsible for creating ghettos and barrios, it was actually the federal government's explicit racial policy that created these enclaves.

Each of these policies, routinely hailed as major progressive government interventions to boost the economy and place a safety net under all citizens, was instrumental in creating long-running patterns of accumulation and disaccumulation based on race. These policies, along with others, institutionalized white advantage over blacks and other people of color.

\section{Racial Equality and the Possessive Investment in Whiteness after the Civil Rights Revolution}

In the post-civil rights era, formal equality before the law coexists with de facto white privilege and whites' resentment of race-conscious remedies. Whites' resentment reflects their "possessive investment in whiteness." 79 Historically, white Americans have accumulated advantages in housing, work, education, and security based solely on the color of their skin. Being white, as a consequence, literally has value. Though race may be a cultural and biological fiction, whiteness, like blackness, is a very real social and legal identity. 
Both identities are crucial in determining one's social and economic status. This is why, when Professor Andrew Hacker asked his white students how much money they would demand if they were changed from white to black, they felt it was reasonable to ask for $\$ 50$ million if they were to be black for the rest of their lives, or \$I million a year for each year they were black. ${ }^{80}$ That was the financial value they placed on being white. It was, to use W. E. B. Du Bois's phrase, the dollar amount they attached to their "wages of whiteness." The idea of a possessive investment in whiteness helps to explain the structures of durable racial inequality and the color-coded community processes of accumulation and disaccumulation. The formation of racial identity, in turn, connects interests to attitudes toward public issues that have racial consequences and color-conscious remedies.

In one important, and ironic, respect, the combination of legal equality with social and economic racial inequality at the end of the civil rights movement is similar to the relationship between blacks and whites at the end of Reconstruction. Plessy $v$. Ferguson, which marked the end of Reconstruction by upholding the doctrine of "separate but equal," was the culmination of a long debate over the meaning of racial equality that began with the abolitionists' struggle against slavery. At the time, it was commonly understood that the Fourteenth Amendment guaranteed equality before the law and that political rights (such as the right to serve as a juror) presumably could not be abrogated. But few believed that the Thirteenth, Fourteenth, or Fifteenth amendments required social or economic equality between blacks and whites. Not even the defenders of a color-blind Constitution accepted this idea. Indeed, Justice John Marshall Harlan's defense of a color-blind Constitution in his dissenting opinion in Plessy explicitly assumed the inferiority of African Americans and distinguished between legal and social equality. ${ }^{81}$ The stigma of slavery lingered long after "the peculiar institution" was dismantled. As Tocqueville observed about the antebellum North, "The prejudice rejecting the Negroes seems to increase in proportion to their emancipation, and inequality cuts deep into mores as it is effaced from the laws." 82

Americans still face the question of what racial inequality means and what the nation is obligated to do about it. The civil rights movement repudiated racial classifications as a means to subordinate racial groups, and for most Americans that is sufficient. The contemporary controversy over the civil rights policies, however, cannot be reduced, no matter how hard racial realists try, to a debate over repealing color-conscious remedies like affirmative action. The larger question facing Americans is whether equality requires a commitment to go beyond formal legal equality and to rectify three hundred years of racial oppression and subordination. Racial realists and conserva- 
tives think a color-blind Constitution means that public remedies to end social inequality between racial groups are illegitimate, the equivalent of "racial social engineering." This view sharply distinguishes between public and private spheres of action. Government should be held to a strict standard of racial neutrality, proponents argue; the use of laws (or policies) to rectify racial inequalities is wrong.

We reject this position. If America is to achieve a larger measure of racial equality, we think the government must use public policies to root out enduring racial inequality. This does not mean we think affirmative action plans are the remedy. Arguments over affirmative action do not help us understand the etiology and persistence of white privilege. Nor do they help find ways to achieve genuine racial equality. We think it makes more sense to consider carefully how labor market discrimination, private institutional practices, and public policies have generated the accumulation of economic and social advantages in white communities, and the concomitant disaccumulation of social and economic capital in communities of color. By comparing the assumptions, arguments, and evidence articulated by racial realists to an alternative framework, we think it is possible to see the major differences between these two perspectives and the remedies that follow from a theory that focuses on cumulative inequalities.

\section{Notes}

I. Donald R. Kinder and Tali Mendelberg, "Individualism Reconsidered: Principles and Prejudice in Contemporary American Opinion," in David O. Sears, Jim Sidanius, and Lawrence Bobo, eds., Racialized Politics: The Debate about Racism in America (Chicago: University of Chicago Press, 2000), 6I.

2. Jim Sleeper, Liberal Racism (New York: Penguin Books, I997), 7, I75.

3. Tamar Jacoby, Someone Else's House: America's Unfinished Struggle for Integration (New York: The Free Press, I 998), 4-5, 9.

4. Whether opposition to color-conscious policies is motivated by adherence to political principles or reflects a new manifestation of white racism is the subject of many of the essays in Sears, Sidanius, and Bobo, eds., Racialized Politics: The Debate about Racism in America. The wages of full-time male workers have risen only I.3 percent since 1989. Alexander Stille, "Grounded by an Income Gap: Inequality Just Keeps Growing in the U.S.," New York Times, December I 5,200 I, A I 5 .

5. Southern Democrats and conservative Republicans from the Southwest, including Barry Goldwater and George H. W. Bush, the latter representing a conservative Texas constituency in Congress at the time, voted against the 1964 Civil Rights Act.

6. David Garrow, Bearing the Cross: Martin Luther King, Jr., and the Southern Christian Leadership Conference (New York: Vintage Books, 1988), 439.

7. Martin Luther King Jr., "A Testament of Hope," in James M. Washington, ed., A Testa- 
ment of Hope: The Essential Writings of Martin Luther King, Jr. (New York: Harper and Row, I986), 3 I6.

8. Robert L. Carter, "A Reassessment of Brown v. Board," in Derrick Bell, ed., Shades of Brown: New Perspectives on School Desegregation (New York: Teacher's College, Columbia University, I980), 23-24. Brown I declared "separate but equal" unconstitutional in I954. In Brown II, decided in 1955, the Court ruled that local jurisdictions should desegregate with "all deliberate speed."

9. Jim Sleeper, The Closest of Strangers: Liberalism and the Politics of Race in America (New York: W. W. Norton, I990), I60.

Io. Sleeper, Liberal Racism, 9, 77-78.

I I. Paul M. Sniderman and Thomas Piazza, The Scar of Race (Cambridge, Mass.: Harvard University Press, 1993), I03.

I2. For recent examples, see, among others, Terry Eastland, "Endgame for Affirmative Action," Wall Street Journal, March 28, I996; Todd Gaziano, "The New 'Massive Resistance," Policy Review 89 (1998): 22-29; John H. McWhorter, Losing the Race: Self-Sabotage in Black America (New York: Free Press, 2000).

I3. Dinesh D'Souza, The End of Racism: Principles for a Multiracial Society (New York: The Free Press, 1995), chapter I2.

I4. Jacoby, Someone Else's House, , Io.

I5. Sleeper, Liberal Racism, 4 .

I6. Stephen Thernstrom and Abigail Thernstrom, America in Black and White: One Nation, Indivisible (New York: Simon and Schuster, I997), 495, 498, 505; Jacoby, Someone Else's House, 9, 539-40.

I7. Alan Wolfe, "Enough Blame to Go Around," New York Times Book Review, June 2I, I $998, \mathrm{I} 2$.

I8. Thernstrom and Thernstrom, America in Black and White, 299-300; D'Souza, End of Racism, chapter 6.

I9. Sleeper, Liberal Racism, 178 .

20. Dr. Martin Luther King Jr., "I Have a Dream," in James Washington, ed., A Testament of Hope, 219; Sleeper, Liberal Racism, 178.

2I. Conservative writers and think tanks have been in the forefront of the fight against affirmative action and other color-conscious policies. The D'Souza and Thernstrom books in particular are typical of conservative criticism of liberal policies. The research for America in Black and White was underwritten by many of the most influential conservative foundations, including the John M. Olin Foundation, the Smith Richardson Foundation, the Earhart Foundation, and the Carthage Foundation. Jacoby's research was sponsored by many of the same foundations. Both Jacoby and Abigail Thernstrom have been affiliated with the Manhattan Institute, an influential conservative think tank in New York City.

22. Thernstrom and Thernstrom, America in Black and White, I 89-94; see also James Smith and Finis Welch, Closing the Gap: Forty Years of Economic Progress for Blacks (Santa Monica, Calif:: Rand Corporation, I986). The Thernstroms' interpretation of black economic progress assumes that labor market discrimination was not a serious obstacle to good jobs and high wages for black workers after World War II. If this version of history is wrong and labor market discrimination was the cause of low wages and high unemployment, it would make little difference if blacks acquired more education. The Thernstroms' argument is implausible, and there is little evidence to support it. It rests on their assertion that the black unemployment rate was only slightly higher than the white unemployment rate in I940, but twice as many blacks in the North 
were unemployed as in the South. This, the Thernstroms say, is "exactly the opposite of what we would expect if unemployment had been mainly the result of discrimination" since one would expect Mississippi employers to treat blacks less fairly than employers in the North (Thernstrom and Thernstrom, America in Black and White, 245). The Thernstroms are wrong to presume that labor market discrimination was unimportant in the North. In the late I930s, black unemployment rates in northern cities were two to four times higher than white unemployment rates, mainly because of the virulent labor market discrimination unleashed during the Depression when white workers displaced blacks. See Michael K. Brown, Race, Money, and the American Welfare State (Ithaca: Cornell University Press, I999), 68-70; W. A. Sundstrom, "Last Hired, First Fired? Unemployment and Black Workers during the Great Depression," The Journal of Economic History, 52 (I99I): 4 I 5-29. Moreover, unemployment figures for blacks in the South are misleading because seasonal workers (mainly farm workers) were excluded, and many of those reported as employed were unpaid family workers, which is "often little better than a make-shift activity for sons and daughters of farmers [and sharecroppers] when they cannot find other employment." U.S. Bureau of the Census, Sixteenth Census of the United States: I940, Population, vol. 3, The Labor Force, part I: U.S. Summary (Washington, D.C.: U. S. Government Printing Office, 1943), 5, 7. There is no reason to presume that the difference in unemployment rates reflects a lack of discrimination in the South.

23. For a clear statement of this argument, see James A. Heckman, "Detecting Discrimination," Journal of Economic Perspectives I 2 (I998): IoI-I6; for a critique, see William A. Darity Jr. and Patrick L. Mason, "Evidence on Discrimination in Employment: Codes of Color, Codes of Gender," Journal of Economic Perspectives I2 (1998): 63-90.

24. Richard Epstein, Forbidden Grounds: The Case against Employment Discrimination Laws (Cambridge, Mass.: Harvard University Press, 1992), 32. It should be noted that in his original statement of the economic theory of discrimination, Gary Becker acknowledged labor market discrimination and set out to explain why it occurred in specific circumstances. See Gary Becker, The Economics of Discrimination, 2nd ed. (Chicago: University of Chicago Press, I971).

25. Epstein, Forbidden Grounds, 46. Epstein does not assume that segregation leads to wage differences. Wage discrimination and segregation are separate phenomena.

26. Lawrence D. Bobo and Ryan A. Smith, "From Jim Crow Racism to Laissez-Faire Racism: The Transformation of Racial Attitudes," in Wendy F. Katkin, Ned Landsman, and Andrea Tyree, eds., Beyond Pluralism: The Conception of Groups and Identities in America (Urbana: University of Illinois Press, I998), 2 I 2.

27. Thernstrom and Thernstrom, America in Black and White, 183.

28. U.S. Bureau of the Census, "Raw and Hispanic Origin of Householder-Families by Median and Mean Income: 1947 to $200 \mathrm{I}$ " (Table F-5), Historical Income Tables-Families, http://www.census.gov/hhes/income/histinc/fo5.html (accessed October 9, 2002).

29. Ibid. See also Sheldon Danziger and Peter Gottschalk, America Unequal (New York: Russell Sage Foundation, 1995), 7 I-73. Using a measure of income that adjusts for family size and unrelated individuals, Danziger and Gottschalk show that in I99I the real median income of black families was $\mathrm{I} .85$ times the poverty line, compared to 3.54 times for white families. Not until I99I did black family income reach a level comparable to 1959 family income for the total population. Among nonelderly, two-parent families the ratio rose from 44 percent to $7 \mathrm{I}$ percent in I99I, still a large gap. In $200 \mathrm{I}$, after the economic expansion, black married couples' income was 80 percent of white married couples'. However, this measure is not comparable to Danziger's and Gottschalk's and may overstate the ratio. 
30. U.S. Bureau of the Census, "Race and Hispanic Origin of People by Median Income and Sex: 1947 to 2,00I" (Table P-2), Historical Income Tables-People, http://www.census.gov/ hhes/income/histinc/poz.html (accessed October 9, 2002).

3I. Council of Fconomic Advisers, Changing America (Washington D.C.: U.S. Government Printing Office, I998), 28. Many economists point out that it makes no sense to exclude unemployed or part-time black workers from these comparisons. Doing so inflates the relative income gain of black workers because low-income black workers (who have higher unemployment rates) and high-income white workers (who presumably retire early) are excluded from the calculations. This biases estimates of black-white earnings ratios upward. See William Darity Jr. and Samuel Myers Jr., Persistent Disparity: Race and Economic Inequality in the United States since 1945 (Northampton, Mass.: Edward Elgar Publishing, 1998), 46-47.

32. Douglas Massey and Nancy Demon, American Apartheid: Segregation and the Making of the Underclass (Cambridge, Mass.: Harvard University Press, 1993), 77, 87-88.

33. Preliminary studies conducted by the National Fair Housing Alliance reveal how this gap is created. The Alliance found that when creditworthy whites approach subprime lenders, they are systematically referred to prime lenders, who make loans on more favorable terms, with lower interest rates and less predatory foreclosure practices.

34. The ratio of black-white infant mortality rate rose from I.94 in 1980 to 2.35 in 1998 . National Center for Health Statistics, "Infant Mortality Rates, Fetal Mortality Rates, and Perinatal Mortality Rates, according to Race: United States, Selected Years 1950-99" (Table 23), Centers for Disease Control, http://www.cdc.gov/nchs/products/pubs/pubd/hus/tables/200I/ orhus023.pdf (accessed October 9, 2002).

35. David Barton Smith, Health Care Divided: Race and Healing a Nation (Ann Arbor: University of Michigan Press, 1999), 2 10. Smith notes that the National Center for Health Statistics' 1996-97 report documents that blacks' mortality rates are twice as high as those of whites for years of life lost before the age of seventy-five per 100,000 in population.

36. In 1986, for example, among males under 65 , those with the highest educational attainment showed the largest relative racial discrepancies in mortality rates. For adult females, the largest relative racial disparity in mortality rates is found in the highest income category. Gregory Pappas et al., "The Increasing Disparity in Mortality between Socioeconomic Groups in the United States, 1960 and 1986," New England Journal of Medicine 329 (1987): 103-9.

37. Testimony of Ed Mendoza, Assistant Director, Special Initiatives and Program Evaluation, Office of Statewide Health Planning and Development, before Joint Hearing of the California Senate Committee on Business and Professions and the California Senate Committee on Health and Human Services, March 3 I, I 997, Handout \# 4, I, I I (unpublished document on file with authors).

38. Smith, Health Care Divided, $20 \mathrm{I}$.

39. Elizabeth White, "Special Report: Public Health Racial and Ethnic Disparities," Health Care Policy Report 9 (2.00I): 3 I 5 ; "40\% Rise Reported in Asthma and Asthma Deaths," New York Times, January 7, I995, section 2, Io; “Asthma Toll Is Up Sharply, US Reports," New York Times, May 3, 1996, CI 8.

40. Smith, Health Care Divided, 208, table 6.8.

4I. Charles Tilly, Durable Inequality (Berkeley and Los Angeles: University of California Press, I998), I 7 .

42. This is misleading because the small decline in residential segregation occurred largely in cities with very small black populations. See Massey and Denton, American Apartheid, 66, $22 \mathrm{I}-23$.

43. Thernstrom and Thernstrom, America in Black and White, 219-30. 
44. Sally Satel, PC, M.D., How Political Correctness Is Corrupting Medicine (New York: Basic Books, Inc., 2000), 2, 23.

45. Ruth Milkman and Eleanor Townsend, "Gender and the Economy," in Neil J. Smelser and Richard Swedberg, eds., Handbook of Economic Sociology (Princeton: Princeton University Press, I994), 6I I; cited in Tilly, Durable Inequality, 3 I.

46. William Darity Jr., "What's Left of the Economic Theory of Discrimination," in Steven Shulman and William Darity Jr., eds., The Question of Discrimination (Middletown, Conn.: Wesleyan University Press, I989), 335-74. Economists have advanced a variety of ingenious explanations for the persistence of racial discrimination; all of these assume (at least implicitly) that discrimination is temporary and all are based on individual-level explanations. See Darity and Mason, "Evidence of Discrimination in Employment," $8 \mathrm{I}-87$, for a summary. However, James Heckman points out that a bigoted employer can "indulge that taste so long as income is received from entrepreneurial activity" - so long, that is, as there is a willingness to pay the price. See Heckman, "Detecting Discrimination," I I 2.

47. Peter V. Marsden, "The Hiring Process: Recruitment Methods," American Behavioral Scientist 7 (1994): 979-9I; Shazia R. Miller and James E. Rosenbaum, "Hiring in a Hobbesian World," Work and Occupations 24 ( I997): 498-523.

48. Philip Kasinitz and Jay Rosenberg, "Missing the Connection: Social Isolation and Employment on the Brooklyn Waterfront," Social Problems 43 (1996): 180-96; for a description see Thomas Sugrue, The Origins of the Urban Crisis (Princeton: Princeton University Press, I996), chapter 4 .

49. Tilly, Durable Inequality, 9 I.

50. Economists have developed a very similar theory to Tilly's idea of opportunity hoarding; see Derek Leslie, An Investigation of Racial Disadvantage (Manchester: Manchester University Press, 1998), 33-37.

5 I. Darity and Myers, Persistent Disparity, 58.

52. See Reynolds Parley and Walter Alien, The Color Line and the Quality of Life in America (New York: Oxford University Press, 1989), 247; Stanley Lieberson, A Piece of the Pie: Blacks and White Immigrants since I880 (Berkeley: University of California Press, I980), 294-3 I3. Epstein assumes that at least one employer will be motivated by the bottom line and not by negative stereotypes. But this neglects the pressure that white workers may bring to bear on employers to exclude blacks.

53. Pennsylvania nursing homes have a segregation index of .68, which means that 68 percent of nursing home residents would have to move in order to equalize the distribution of blacks and whites across all homes. The 1990 average segregation index for northern cities was .78 . Some of the segregation in nursing homes is an artifact of residential segregation, but not all of it - the segregation index for Philadelphia nursing homes is .63. Smith, Health Care Divided, 264-65, 267; Massey and Denton, American Apartheid, 222.

54. Smith, Health Care Divided, 267.

55. Ibid., 319-20.

56. William Julius Wilson, The Truly Disadvantaged (Chicago: University of Chicago Press, I987), II.

57. Conley, Being Black, Living in the Red (Berkeley: University of California Press, I999), 152.

58. Thernstrom and Thernstrom, America in Black and White, 197-98.

59. Blacks save I I percent of their income; whites save Io percent. Conley, Being Black, Living in the Red, 29.

60. Todd Lewan and Delores Barcaly, "Torn from the Land: AP Documents Land Taken from 
Blacks through Trickery, Violence and Murder," Associated Press, December 200 I, http:// wire.ap.org/APpackages/torn/ (accessed January 2, 2002).

6I. Conley, Being Black, Living in the Red, $38-39$; Massey and Denton, American Apartheid, $54-55$.

62. Black babies are one and one-third times as likely as whites to suffer from low birth weight and more than three times as likely to suffer very low birth weight. See W. Michael Byrd and Linda A. Clayton, An American Health Dilemma, vol. I, A Medical History of African Americans and the Problem of Race: Beginnings to I 900 (New York: Routledge, 2000), 30.

63. Among black children one to six years of age, I I. 5 percent had elevated blood lead levels in I99I-94, compared to 2.6 percent of white children of the same age. U.S. Department of Health and Human Services, Healthy People 2010 : Understanding and Improving Health, 2nd ed. (Washington, D.C.: U.S. Government Printing Office, 2000), 8-2 I.

64. Marianne Means, "Refocus Racism Conference Agenda," San Francisco Chronicle, August I3, 200I, A I7.

65. Ian Haney-Lopez, White by Law: The Legal Construction of Race (New York: New York University Press, I996), I; see also Mary Francis Berry, Black Resistance, White Law (New York: Penguin Books, I995).

66. See George Fredrickson, The Arrogance of Race (Middletown, Conn.: Wesleyan University Press, I988), and White Supremacy (New York: Oxford University Press, 198I); and Leon A. Higginbotham, In the Matter of Color: Race and the American Legal Process (New York: Oxford University Press, 1978).

67. Dred Scott v. Sanford, 19 How. (60 U.S.) 393 (1 857 ).

68. Vincent Harding, There Is a River: The Black Struggle for Freedom in America (New York: Oxford University Press, 1983), $20 \mathrm{I}$.

69. Stephen Steinberg, Turning Back: The Retreat from Racial Justice in American Thought and Policy (Boston: Beacon Press, I995).

70. Jill Quadagno, The Color of Welfare (New York: Oxford University Press, I994), I9-I4.

7I. Brown, Race, Money, and the American Welfare State, $7 \mathbf{I}$.

72. Ibid, 82; U.S. Congress, Senate, Committee on Finance, Economic Security Act Hearings on $S .1130,74$ th Congress, Ist Session, I935, 64I.

73. Brown, Race, Money, and the American Welfare State, 82.

74. Quadagno, The Color of Welfare, I60-6I.

75. Robert Lieberman, Shifting the Color Line: Race and the American Welfare State (Cambridge, Mass.: Harvard University Press, 1998), 198-99, 2 10.

76. Brown, Race, Money, and the American Welfare State, chapters 2. and 5.

77. Herbert Hill, Black Labor and the American Legal System (Madison: University of Wisconsin Press, 1985), 105; Quadagno, The Color of Welfare, 23; Brown, Race, Money, and the American Welfare State, 68.

78. Irving Bernstein, Promises Kept: John F. Kennedy's New Frontier (New York: Oxford University Press, I99I), I 65-67.

79. George Lipsitz, The Possessive Investment in Whiteness: How White People Profit from Identity Politics (Philadelphia: Temple University Press, I998).

80. Andrew Hacker, Two Nations (New York: Ballantine Books, 1992,), 32.

8I. Reva B. Siegel, "The Racial Rhetorics of Color-Blind Constitutionalism: The Case of Hopwood v. Texas," in Robert Post and Michael Rogin, eds., Race and Representation: Affirmative Action (New York: Zone Books, I998), 49-50.

82. Alexis de Tocqueville, Democracy in America (1835; reprint, New York: Anchor Books, I969), 344 . 